\title{
Analysis of changes in microRNA expression profiles in response to the troxerutin-mediated antioxidant effect in human dermal papilla cells
}

\author{
KYUNG MI LIM ${ }^{1 *}$, SUNGKWAN AN $^{1 *}$, OK-KYU LEE ${ }^{1}$, MYUNG JOO LEE $^{1}$, JEONG PYO LEE $^{2}$, \\ KWANG SIK LEE ${ }^{2}$, GHANG TAI LEE ${ }^{2}$, KUN KOOK LEE ${ }^{2}$ and SEUNGHEE BAE ${ }^{1}$ \\ ${ }^{1}$ Molecular-Targeted Drug Research Center and Korea Institute for Skin and Clinical Sciences, Konkuk University, \\ Seoul 143-701; ${ }^{2}$ Coreana Cosmetics Co., Ltd., Cheonan, Chungcheong 330-882, Republic of Korea
}

Received July 19, 2014; Accepted March 26, 2015

DOI: $10.3892 / \mathrm{mmr} .2015 .3717$

\begin{abstract}
Dermal papilla (DP) cells function as important regulators of the hair growth cycle. The loss of these cells is a primary cause of diseases characterized by hair loss, including alopecia, and evidence has revealed significantly increased levels of reactive oxygen species (ROS) in hair tissue and DP cells in the balding population. In the present study, troxerutin, a flavonoid derivative of rutin, was demonstrated to have a protective effect against $\mathrm{H}_{2} \mathrm{O}_{2}$-mediated cellular damage in human DP (HDP) cells. Biochemical assays revealed that pretreatment with troxerutin exerted a protective effect against $\mathrm{H}_{2} \mathrm{O}_{2}$-induced loss of cell viability and $\mathrm{H}_{2} \mathrm{O}_{2}$-induced cell death. Further experiments confirmed that troxerutin inhibited the $\mathrm{H}_{2} \mathrm{O}_{2}$-induced production of ROS and upregulation of senescence-associated $\beta$-galactosidase activity. Using microRNA (miRNA) microarrays, the present study identified 24 miRNAs, which were differentially expressed in the troxerutin-pretreated, $\mathrm{H}_{2} \mathrm{O}_{2}$-treated HDP cells. Subsequent prediction using bioinformatics analysis revealed that the altered miRNAs were functionally involved in several cell signaling pathways, including the mitogen-activated protein kinase and WNT pathways. Overall, these results indicated that ROS-mediated cellular damage was inhibited by troxerutin and suggested that the use of troxerutin may be an effective approach in the treatment of alopecia.
\end{abstract}

Correspondence to: Professor Seunghee Bae, Molecular-Targeted Drug Research Center and Korea Institute for Skin and Clinical Sciences, Konkuk University, 120 Neungdong-ro, Gwangjin, Seoul 143-701, Republic of Korea

E-mail: sbae@konkuk.ac.kr

${ }^{*}$ Contributed equally

Key words: microRNA, troxerutin, antioxidant effect, dermal papilla cells, senescence

\section{Introduction}

Trihydroxyethylrutoside (troxerutin) is one of the flavonoid rutoside derivatives. It exhibits non-mutagenic properties and has a functional role in the treatment of chronic venous insufficiency (CVI) (1,2). A number of studies have demonstrated other beneficial effects of troxerutin, in vitro and in vivo, and it may be effective in reducing different cytotoxicities. In particular, troxerutin has been observed to exhibit an inhibitory effect on the neurotoxicity induced by high cholesterol-mediated cognitive deficits, kainic acid-triggered excitotoxic damage and $\beta$-amyloid oligomerization (3-5). In addition, troxerutin has a photoprotective effect against ultraviolet B (UVB) radiation in human skin cells, including dermal fibroblasts and keratinocytes $(6,7)$. Troxerutin also exerts a protective effect against $\gamma$-radiation in mice $(8,9)$. Although the precise cellular mechanisms underlying the effects of troxerutin remain to be fully elucidated, these reports can be summarized as a single meaningful finding, that troxerutin inhibits the production of reactive oxygen species (ROS). In vivo investigations have demonstrated that CVI-bearing patients have increased levels of ROS, and troxerutin has a protective effect against oxygen-derived free radical scavengers on the endothelium in these patients $(10,11)$. In addition, the aforementioned neurotoxicities are inhibited following troxerutin application by reducing the production of ROS $(3,4,12)$. UVB and $\gamma$-radiation are known ROS stimulators $(13,14)$, and a previous study demonstrated that troxerutin protects against radiation-induced lipid peroxidation (9). These studies suggest that this toxerutin may offer a novel therapeutic strategy for ROS-induced diseases.

Dermal papilla (DP) cells are located at the base of hair follicles and are important in the induction of growth and maintenance of epithelial cells, which are the predominant components of hair follicles (15). In response to hormonal changes, DP cells direct the follicular epithelial cells to enter the hair growth cycle, which involves anagen, an active growing phase; catagen, a short transitionary regressive phase; and telogen, a dormant resting phase (15). An increasing body of evidence has demonstrated excessive loss of viability and death of DP cells in balding regions of the scalp, 
compared with non-balding regions, due to increased levels of 5 $\alpha$-reductase (16), a converting enzyme for androgenic hormones and intracellular ROS (17). In addition, previous reports have indicated that oxidative stress is generated by the exposure of androgen-sensitive prostate cancer cells to high levels of androgens (18), and that lipid peroxides increase the levels of ROS and apoptosis of the hair follicle cells (19). Furthermore, DP cells in the balding scalp grow more slowly in vitro, compared with cells from the non-balding scalp. The reduced proliferative activity of balding DP cells is associated with changes in the expression levels of senescence-associated (SA) $\beta$-galactosidase, oxidative stress markers, superoxide dismutase and catalase (20). These findings indicate that oxidative stress is important in the loss of DP cells and in hair production.

In the present study, the hypothesis that troxerutin inhibits ROS-mediated cellular dysfunction in human DP (HDP) cells was investigated. In addition, using micro (mi)RNA microarrays and bioinformatics analysis, the role of troxerutin in the regulation of the expression and mechanisms of specific miRNAs was evaluated. The present study aimed to examine troxerutin as a potential novel chemical agent for the prevention and/or treatment of alopecia.

\section{Materials and methods}

Cell culture and viability. The HDP cells were purchased from Innoprot (Biscay, Spain) and cultured in Dulbecco's modified Eagle's medium, containing 10\% fetal bovine serum (FBS; Thermo Fisher Scientific, Waltham, MA, USA) and $1 \%$ penicillin-streptomycin (Gibco Life Technologies, Grand Island, NY, USA) at $37^{\circ} \mathrm{C}$ and $5 \% \mathrm{CO}_{2}$. The cells were plated at a density of $4 \times 10^{3} /$ well in a 96 -well plate. At $70-80 \%$ confluence, the cells were treated with troxerutin (Sigma-Aldrich, St. Louis, MO, USA) at concentrations ranging between 0 and $60 \mu \mathrm{M}$ for $24 \mathrm{~h}$ at $37^{\circ} \mathrm{C}$. Subsequently, $10 \mu \mathrm{l}$ water-soluble tetrazolium salt assay solution (EZ-Cytox Cell Viability Assay kit; Itsbio, Seoul, Korea) was added to each well and, following incubation for $30 \mathrm{~min}$ at $37^{\circ} \mathrm{C}$, the optical density was measured at $490 \mathrm{~nm}$ using an iMark microplate reader (Bio-Rad Laboratories, Inc., Hercules, CA, USA). To examine troxerutin-mediated ROS protection, the cells were pretreated with troxerutin at the following concentrations: $0,5,10$ and $15 \mu \mathrm{M}$ for $8 \mathrm{~h}$. Subsequently, $750 \mu \mathrm{M} \mathrm{H}_{2} \mathrm{O}_{2}$ was added to each well. Following incubation for $24 \mathrm{~h}$ at $37^{\circ} \mathrm{C}$, cell viability was evaluated using an EZ-Cytox Cell Viability Assay kit. The level of cell viability (\%) was normalized to that of $0.1 \%$ dimethyl-sulfoxide (DMSO; Sigma-Aldrich)-treated cells. Each experiment was repeated at least three times. The $\mathrm{P}$-value was determined using Student's t-test and $\mathrm{P}<0.05$ was considered to indicate a statistically significant difference.

Analysis of cell cycle. The HDP cells $\left(2 \times 10^{6}\right)$, which had been treated with troxerutin and/or $\mathrm{H}_{2} \mathrm{O}_{2}$ were trypsinized using $0.25 \%$ trypsin-EDTA (Gibco Life Technologies), washed once with phosphate-buffered saline (PBS), and used for analysis. The cell cycle distribution was measured using propidium iodide (PI; Sigma-Aldrich) staining solution, containing $50 \mu \mathrm{g} / \mathrm{ml}$ PI, $0.5 \%$ Triton X-100 (Sigma-Aldrich) and $100 \mu \mathrm{g} / \mathrm{ml}$ RNase (Qiagen, Hilden, Germany). The cells were fixed in 70\% cold ethanol (Merck Millipore, Darmstadt, Germany) and incubated for $1 \mathrm{~h}$ at $-20^{\circ} \mathrm{C}$. Subsequently, PI staining solution was added to the fixed cells, followed by incubation for $1 \mathrm{~h}$ in the dark at $37^{\circ} \mathrm{C}$. The PI fluorescence intensity was detected using a BD FACSCalibur flow cytometer (BD Biosciences, San Jose, CA, USA). The mean PI fluorescence intensity was calculated based on the measurements of 10,000 cells using the FL2-H channel.

Analysis of intracellular levels of ROS. The HDP cells $\left(2 \times 10^{6}\right)$, which had been treated with troxerutin and/or $\mathrm{H}_{2} \mathrm{O}_{2}$ were washed with PBS and trypsinized. Intracellular ROS levels were measured using 2'7'-dichlorofluorescein diacetate fluorescent dye (DCF-DA; Sigma-Aldrich), as described previously (21). The cells were resuspended in $10 \mu \mathrm{M}$ DCF-DA and further incubated at room temperature for $1 \mathrm{~h}$ in the dark. The intensity of the resulting fluorescence was measured using a BD FACSCalibur flow cytometer (BD Biosciences). The mean DCF fluorescence intensity was calculated based on measurements of 10,000 cells using the FL1-H channel. The M1 range was calculated as the percentage of each subpopulation of cells exhibiting increased DCF-DA fluorescence.

Analysis of cellular senescence. The HDP cells $\left(2 \times 10^{6}\right)$, which had been treated with troxerutin and/or $\mathrm{H}_{2} \mathrm{O}_{2}$ were washed in PBS and fixed for $5 \mathrm{~min}$ at room temperature in $2 \%$ formaldehyde/0.2\% glutaraldehyde (Sigma-Aldrich). The cells were washed with PBS and incubated for $15 \mathrm{~h}$ at $37^{\circ} \mathrm{C}$ with SA $\beta$-galactosidase staining solution (BioVision, Milpitas, CA, USA). The stained cells (blue) were observed using a bright-field microscope (CKX41; Olympus Corporation, Tokyo, Japan; magnification, x200), counted in three different fields and the percentage of stained cells was determined.

Analysis of miRNA expression profiles. The HDP, which had been cells treated with troxerutin and/or $\mathrm{H}_{2} \mathrm{O}_{2}$ were washed in cold PBS and trypsinized for RNA purification. The total RNA was extracted and purified from the cells using TRIzol ${ }^{\circledR}$ reagent (Invitrogen Life Technologies, Carlsbad, CA, USA), according to the manufacturer's instructions. The integrity (RNA integrity number >8.0) and purity (A260/280 and A260/230 values >1.8) were confirmed using an Agilent 2100 Bioanalyzer ${ }^{\circledR}$ (Agilent Technologies, Inc., Santa Clara, CA, USA) and a MaestroNano ${ }^{\circledR}$ microvolume spectrophotometer (Maestrogen, Las Vegas, NV, USA), respectively. Samples (100 ng) of RNA meeting these criteria were first dephosphorylated by incubation with calf intestinal alkaline phosphatase (Agilent Technologies, Inc.) at $37^{\circ} \mathrm{C}$ for $30 \mathrm{~min}$. Subsequently, cyanine 3-pCp labeling solution (Agilent Technologies, Inc.) and T4 RNA ligase (Agilent Technologies, Inc.) were added to the dephosphorylated RNA samples and incubated at $16^{\circ} \mathrm{C}$ for $2 \mathrm{~h}$. Following the labeling reaction, the samples were dried and treated with GE Blocking Agent (Agilent Technologies, Inc.). The samples were hybridized to the SurePrint G3 Human v16 miRNA 8x60 K (Agilent Technologies, Inc.) microarray at $55^{\circ} \mathrm{C}$, with constant rotation at $20 \mathrm{rpm}$ in an Agilent Microarray Hybridization Chamber(Agilent Technologies, Inc.) for $20 \mathrm{~h}$. The array was then washed and scanned using an Agilent SureScan Microarray scanner and the images captured were quantified using Agilent Feature Extraction 
software (version 10.7; Agilent Technologies, Inc.). The data were analyzed with the assistance of GeneSpring GX software version 7.3 (Agilent Technologies). In addition, fold-change analysis was performed to select those with $\geq 2.0$-fold between the $\mathrm{H}_{2} \mathrm{O}_{2}$-treated control cells and those treated with troxerutin and $\mathrm{H}_{2} \mathrm{O}_{2}$.

Bioinformatic analysis of altered miRNAs. Analysis of the biological significance of the altered miRNAs in the present study was performed, as previously described (21). First, the putative target genes of the altered miRNAs were predicted using Micro Cosm Targets Version 5 (http://www.ebi.ac.uk/enright-srv/microcosm/htdocs/targets/v5/). Subsequently, the target genes were grouped into four categories: Aging, skin development, apoptosis and cell proliferation, based on the AmiGo 2 Gene Ontology (GO) analysis tool (amigo.geneontology. org/cgi-bin/amigo/browse.cgi). The putative target genes of each miRNA were further analyzed for biologic function using the Kyoto Encyclopedia of Genes and Genomes (KEGG) pathway within the Database for Annotation, Visualization and Integrated Discovery, (DAVID; http://david.abcc.ncifcrf. gov/home.jsp) bioinformatics resources (version 6.7), according to the standard procedures (22). The 'KEGG_pathway' category was processed by setting the threshold of the EASE score, a modified Fisher's exact P-value, to 0.1. The KEGG pathways, identified as having a percentage of involved target genes / total target genes in each pathway $>1 \%$ were selected.

\section{Results}

$\mathrm{H}_{2} \mathrm{O}_{2}$-induced cell damage is inhibited by troxerutin in HDP cells. HDP cells are a major component of skin and direct hair growth, and loss or senescence of these cells is a key cause of hair loss (15). Previous reports have demonstrated that cisplatin- and androgen overexposure-mediated cellular dysfunction, including apoptosis, can induce alopecia and occur predominantly by stimulating the production ROS in HDP cells $(16,23,24)$. In our previous study, pretreatment of human dermal fibroblasts and $\mathrm{HaCaT}$ keratinocytes with troxerutin was observed to protect against UVB-mediated cell death $(6,7)$. UVB light is an important inducer of ROS production in several types of cell (13); therefore, the present study examined the possible role of troxerutin in protecting against ROS-induced cell stress and damage in HDP cells. Initially, troxerutin-mediated cytotoxicity in HDP cells was screened for. No significant changes in cell viability were detected following treatment with between 0 and $60 \mu \mathrm{M}$ troxerutin for $24 \mathrm{~h}$ (Fig. 1A), indicating that troxerutin was non-toxic in the HDP cells. Subsequently, the protective role of troxerutin against ROS-induced cell damage was determined using $\mathrm{H}_{2} \mathrm{O}_{2}$, a ROS inducer. The HDP cells were pretreated with several concentrations $(0-60 \mu \mathrm{M})$ of troxerutin for $6 \mathrm{~h}$, followed by the addition of $750 \mu \mathrm{M} \mathrm{H}_{2} \mathrm{O}_{2}$ and incubation for an additional $24 \mathrm{~h}$. The results revealed that the maximum protective effect against ROS-induced cell damage in the HDP cells occured folowing pretreatment with $10 \mu \mathrm{M}$ troxerutin (Fig. 1B). Treatment with $\mathrm{H}_{2} \mathrm{O}_{2}$ alone decreased cell viability to $77.33 \pm 2.44 \%$; however, pretreatment with $10 \mu \mathrm{M}$ troxerutin maintained cell viability at $90.88 \pm 2.24 \%$ following
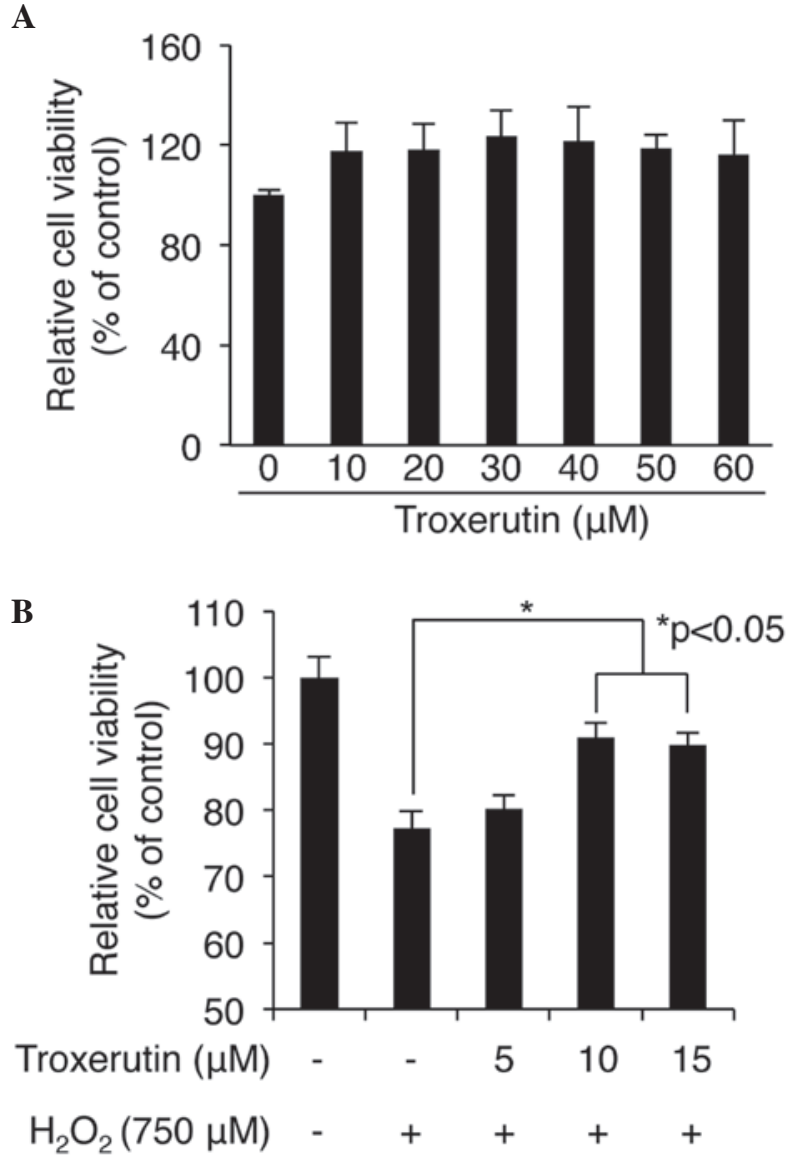

Figure 1. Troxerutin protects HDP cells against the $\mathrm{H}_{2} \mathrm{O}_{2}$-mediated reduction in viability. The viability of the (A) HDP cells treated with the indicated doses of troxerutin and in (B) HDP cells pretreated with the indicated doses of troxerutin followed by treatment with $\mathrm{H}_{2} \mathrm{O}_{2}$, were assessed. The results are presented as the mean \pm standard derivation of three independent experiments. ${ }^{*} \mathrm{P}<0.05$, compared with control $\mathrm{H}_{2} \mathrm{O}_{2}$-treated sample. HDP, human dermal papilla.

$\mathrm{H}_{2} \mathrm{O}_{2}$ exposure $(\mathrm{P}<0.05$; Fig. 1B). Concentrations of troxerutin $>15 \mu \mathrm{M}$ did not significantly enhance the protective effect of $10 \mu \mathrm{M}$ troxerutin (Fig. 1B and data not shown). These results suggested that pretreatment with troxerutin inducedresistance against $\mathrm{H}_{2} \mathrm{O}_{2}$-mediated cytotoxicity in the HDP cells.

$\mathrm{H}_{2} \mathrm{O}_{2}$-induced cell death is inhibited by troxerutin in $\mathrm{HDP}$ cells. Our previous study demonstrated that troxerutin effects the level of cell death induced by UVB irradiation $(6,7)$ and Fig. 1 shows the protective role of troxerutin against ROS-induced cell damage, observed in the present study. Therefore, to examine whether troxerutin is involved in the response to ROS stress, which is known to inhibit cell-cycle progression and induce cell death, the present study investigated changes in the cell cycle and in cell death in the HDP cells pretreated with different concentrations of troxerutin prior to $\mathrm{H}_{2} \mathrm{O}_{2}$ exposure. The HDP cells were pretreated with 0,5 or $10 \mu \mathrm{M}$ troxerutin for $6 \mathrm{~h}$, followed by treatment of the cells with $750 \mu \mathrm{M} \mathrm{H}_{2} \mathrm{O}_{2}$ for an additional $24 \mathrm{~h}$. Subsequently, the cells were analyzed by flow cytometry. At concentrations of 5 and $10 \mu \mathrm{M}$, pretreatment with troxerutin caused a decrease in the number of cells in the sub-G1 phase, indicative of cell death (Fig. 2A). $\mathrm{H}_{2} \mathrm{O}_{2}$ increased the 
A

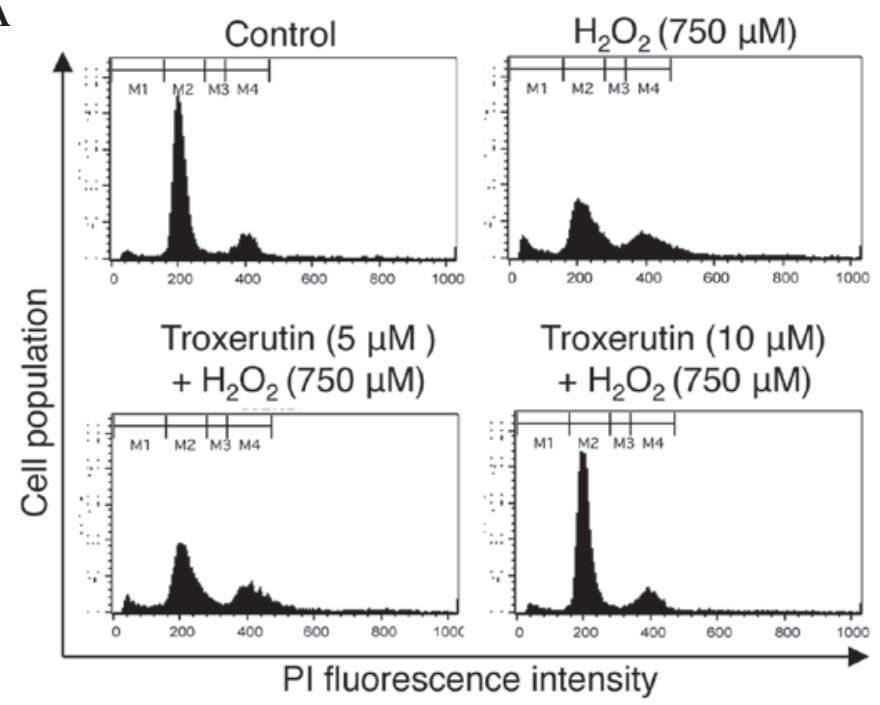

B

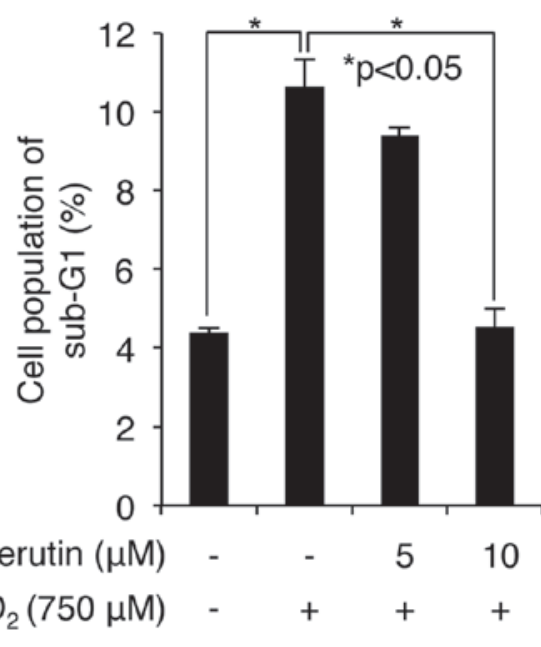

Figure 2. Troxerutin inhibits G2 phase arrest and cell death induced by $\mathrm{H}_{2} \mathrm{O}_{2}$ exposure in HDP cells. (A) Flow cytometric analysis was performed to determine the cell cycle distribution of the control HDP cells, HDP cells treated with $\mathrm{H}_{2} \mathrm{O}_{2}$ only and HDP cells pretreated with the indicated doses of troxerutin followed by treatment with $\mathrm{H}_{2} \mathrm{O}_{2}$. The Sub-G1, G1, S, and G2/M phases were separated using the indicated gates (M1, M2, M3 and M4). (B) Quantification of the percentages of the cell populations in the sub-G1 phase. The results are presented as the mean \pm standard deviation of three independent experiments. ${ }^{*} \mathrm{P}<0.05$, compared with the control or $\mathrm{H}_{2} \mathrm{O}_{2}$-treated cells for indicated pairs. HDP, human dermal papilla; PI, propidium iodide.

A

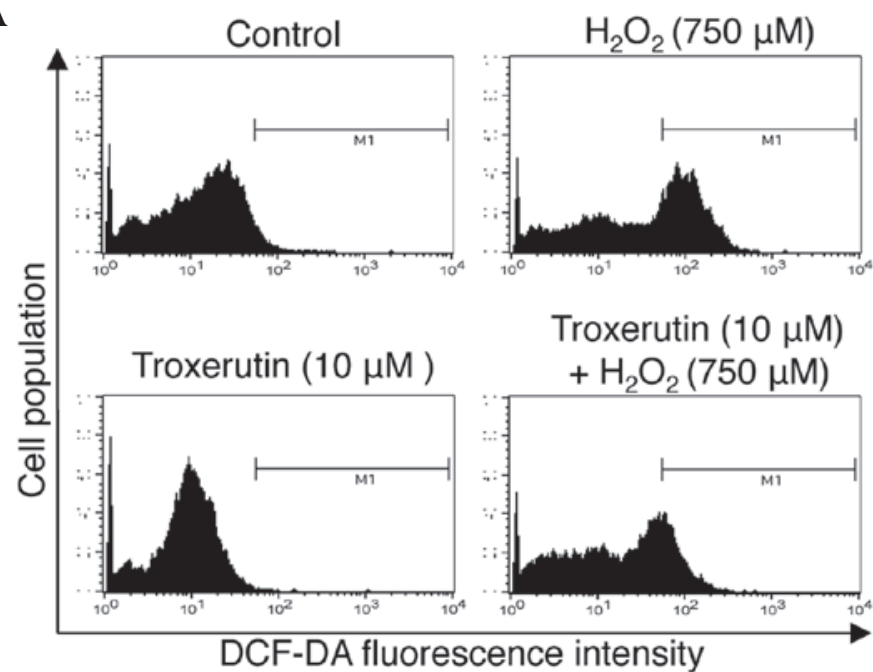

B

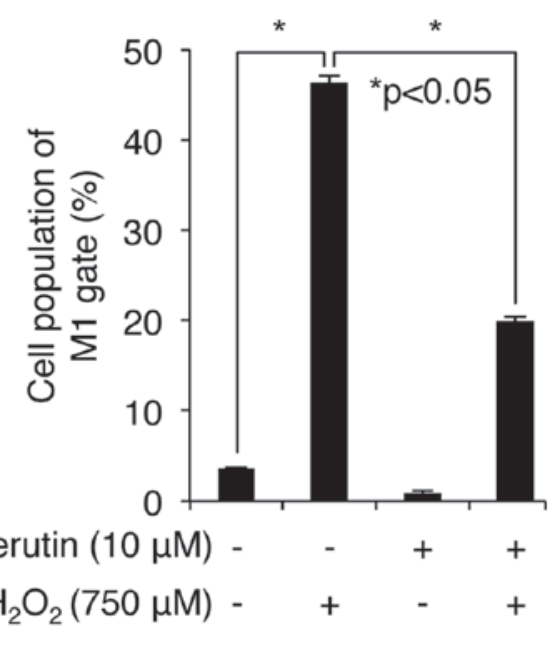

Figure 3. Troxerutin downregulates the level of ROS in HDP cells. (A) Flow cytometric analysis of the intracellular ROS levels in the control HDP cells, HDP cells treated with $\mathrm{H}_{2} \mathrm{O}_{2}$ only and the $\mathrm{HDP}$ cells pretreated with the indicated doses of troxerutin followed by treatment with $\mathrm{H}_{2} \mathrm{O}_{2}$. $\mathrm{M}_{1}$ indicates the subpopulation of cells emitting DCF-DA fluorescence signal. (B) Quantification of the percentage of cells in M1. The results are presented as the mean \pm standard deviation of three independent experiments. ${ }^{*} \mathrm{P}<0.05$, compared with the control or $\mathrm{H}_{2} \mathrm{O}_{2}$-treated sample for indicated pairs. HDP, human dermal papilla; ROS, reactive oxygen species; DMSO, dimethyl sulfoxide; DCF-DA, 2'7'-dichlorofluorescein diacetate.

percentage of the non-pretreated cells in the sub-G1 phase to $10.63 \pm 0.43 \%$; however, this value increased to only $9.38 \pm 0.11$ and $4.53 \pm 0.53 \%$ in the cells pretreated with 5 and $10 \mu \mathrm{M}$ troxerutin, respectively $(\mathrm{P}<0.05$; Fig. $2 \mathrm{~A}$ and $\mathrm{B})$. Therefore, these results suggested that troxerutin overcame the effect of $\mathrm{H}_{2} \mathrm{O}_{2}$-mediated cell death, resulting in a diminution of cells in the sub-G1 phase.

Hydrogen peroxide-induced ROS production is inhibited by troxerutin in HDP cells. Although the above results indicated that troxerutin had a protective effect against $\mathrm{H}_{2} \mathrm{O}_{2}$-mediated cell death, it remained to be elucidated whether troxerutin also regulates the level of intracellular $\mathrm{H}_{2} \mathrm{O}_{2}$-induced ROS in HDP cells. To examine this, the presents study performed a fluorescent DCF-DA staining assay following treatment with troxerutin and $\mathrm{H}_{2} \mathrm{O}_{2}$ in the HDP cells. The DCF-positive cells were then analyzed using flow cytometry to determine and compare the levels of intracellular ROS in the control cells, non-troxerutin-pretreated cells, troxeruti-only-treated cells and troxerutin-pretreated $/ \mathrm{H}_{2} \mathrm{O}_{2}$-treated cells. As shown in Fig. 3, in the control and troxerutin-only-treated cells, $3.58 \pm 0.15$ and $0.89 \pm 0.11 \%$ were $\mathrm{DCF}$-positive $(\mathrm{P}<0.05$; Fig. 3B), suggestive of ROS respectively, whereas treatment with $\mathrm{H}_{2} \mathrm{O}_{2}$ alone increased the level of ROS to $46.36 \pm 2.33 \%$. 
Table I. MicroRNAs with $\geq 2$-fold change in expression in troxerutin-pretreated $\mathrm{H}_{2} \mathrm{O}_{2}$-treated human dermal papilla cells.

\begin{tabular}{|c|c|c|c|}
\hline microRNA & $\begin{array}{l}\text { Change } \\
\text { relative } \\
\text { to control }\end{array}$ & $\begin{array}{l}\text { Direction } \\
\text { of } \\
\text { regulation }\end{array}$ & Chromosome \\
\hline hsa-miR-150-3p & 4.13 & Up & 19 \\
\hline hsa-miR-181a-2-3p & 2.31 & Up & 9 \\
\hline hsa-miR-205-3p & 4.28 & Up & 1 \\
\hline hsa-miR-21-3p & 2.92 & Up & 17 \\
\hline hsa-miR-29b-1-5p & 3.72 & Up & 7 \\
\hline hsa-miR-3127-5p & 2.19 & Up & 2 \\
\hline hsa-miR-371a-5p & 2.30 & Up & 19 \\
\hline hsa-miR-3663-3p & 2.53 & Up & 10 \\
\hline hsa-miR-4298 & 2.01 & Up & 11 \\
\hline hsa-miR-602 & 6.91 & Up & 9 \\
\hline hsa-miR-1181 & -3.14 & Down & 19 \\
\hline hsa-miR-1202 & -2.78 & Down & 6 \\
\hline hsa-miR-1224-5p & -4.66 & Down & 3 \\
\hline hsa-miR-1290 & -2.15 & Down & 1 \\
\hline hsa-miR-135a-3p & -5.61 & Down & 3 \\
\hline hsa-miR-28-5p & -2.95 & Down & 3 \\
\hline hsa-miR-378a-5p & -2.01 & Down & 5 \\
\hline hsa-miR-4271 & -2.16 & Down & 3 \\
\hline hsa-miR-452-5p & -2.51 & Down & $\mathrm{X}$ \\
\hline hsa-miR-572 & -4.26 & Down & 4 \\
\hline hsa-miR-575 & -8.01 & Down & 4 \\
\hline hsa-miR-629-3p & -3.12 & Down & 15 \\
\hline hsa-miR-939 & -2.22 & Down & 8 \\
\hline hsa-miR-940 & -2.30 & Down & 16 \\
\hline
\end{tabular}

miR, microRNA.

The cells pretreated with troxerutin were $19.92 \pm 1.95 \%$ DCF-positive following $\mathrm{H}_{2} \mathrm{O}_{2}$ treatment, indicating that troxerutin reduced the $\mathrm{H}_{2} \mathrm{O}_{2}$-induced production of ROS in the HDP cells.

Hydrogen peroxide-induced senescence is inhibited by troxerutin in HDP cells. Increased ROS are one of the key mediators of cellular senescence (25). A previous report demonstrated that the premature senescence of balding DP cells is associated with changes in the expression of SA $\beta$-galactosidase and also suggested that oxidative stress may be involved in the premature senescence of these cells (20). The present study assayed for the presence of SA $\beta$-galactosidase activity to investigate whether troxerutin affects $\mathrm{H}_{2} \mathrm{O}_{2}$-induced senescence, thereby contributing to its protective effect against ROS-mediated cell damage. $\mathrm{H}_{2} \mathrm{O}_{2}$ treatment increased the number of SA $\beta$-galactosidase-positive cells to $32.11 \pm 3.32 \%$ compared with the control; however, only $18.22 \pm 5.21 \%$ of the cells pretreated with troxerutin were SA $\beta$-galactosidase-positive following treatment with $\mathrm{H}_{2} \mathrm{O}_{2}$ (Fig. 4). These data indicated that troxerutin has the potential to inhibit cellular senescence in HDP cells.
Troxerutin-mediated protective effects against ROS are involved in changes in miRNA expression in HDP cells. The present study also analyzed the miRNA expression profiles of non-pretreated and troxerutin-pretreated HDP cells treated with $\mathrm{H}_{2} \mathrm{O}_{2}$, as miRNAs can be involved in cell death, ROS scavenging and senescence $(21,26-28)$. In the microarray, a total of 24 miRNAs were detected with a $\geq 2$. 0 -fold change in expression levels between the two groups. Among these, 10 miRNAs were upregulated and 14 were downregulated in the $\mathrm{H}_{2} \mathrm{O}_{2}$-treated cell, which had been pretreated with troxerutin (Table I). To investigate the biological value of the microarray data, several bioinformatic analyses were performed to predict the putative target genes of the altered miRNAs, and the GO and signaling pathways of the target genes. The putative target genes of each miRNA were determined using MicroCosm Targets Version 5, following which GO analysis was performed for the target genes. Subsequently, the target genes of each miRNA were categorized into four biological functions: Aging, skin development, apoptosis and cell proliferation. Several target genes of each miRNA were found to be involved in these four biological functions at different levels (Tables II and III). For example, hsa-miR-602, which was the most highly upregulated miRNA (6.91-fold) based on the microarray data, potentially targets 34 genes, six of which were involved in aging, and one of the remaining 28 target genes was involved in skin development (Table II). Similarly, the target genes of the downregulated miRNAs were also differentially involved in the four functions (Table III), indicating that the altered miRNAs identified by the microarray analysis had distinct biological roles associated with the protective effect of troxerutin in $\mathrm{H}_{2} \mathrm{O}_{2}$-treated HDP cells. Therefore, the present study further analyzed the signaling pathways associated with the upregulated and downregulated miRNAs using KEGG pathway analysis and the DAVID bioinformatics tool (22), the results of which are presented in Tables IV and V, respectively. The results demonstrated that the altered miRNAs are functionally involved in shared and unique pathways among the miRNAs. For example, hsa-miR-602 was identified to be functionally involved in MAPK, insulin, and calcium signaling pathways, whereas hsa-miR-205-3p was found to be involved in cancer, MAPK, Wnt and cell adhesion signaling pathways. Overall, these results indicated that the miRNA expression patterns of non-pretreated and troxerutin-pretreated $\mathrm{H}_{2} \mathrm{O}_{2}$-treated HDP cells can be distinguished, and those which are significant changed may be involved in troxerutin-mediated protection against $\mathrm{H}_{2} \mathrm{O}_{2}$-induced cellular stress through the regulation of multiple signaling pathways.

\section{Discussion}

In the present study, the protective effect of troxerutin against $\mathrm{H}_{2} \mathrm{O}_{2}$-induced oxidative stress in HDP cells was confirmed using biochemical assays. Notably, pretreatment with troxerutin decreased the cell death, ROS production and cellular senescence, which was mediated by exposure to $\mathrm{H}_{2} \mathrm{O}_{2}$. Although the specific signaling pathways involved in the protective effect were not demonstrated, the findings of the present study are important in that they identify troxerutin as a candidate agent for use in the prevention and/or treatment of 


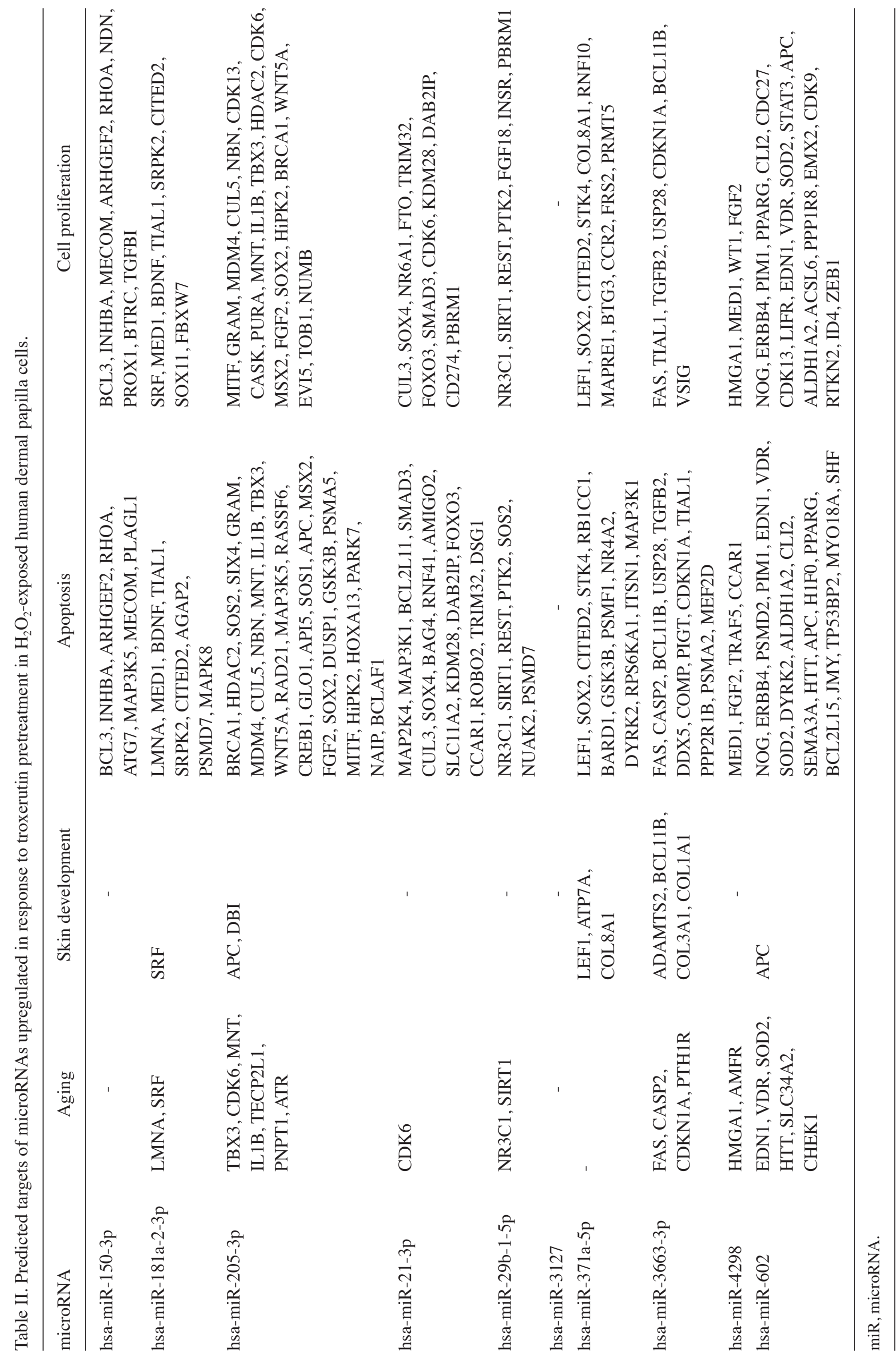




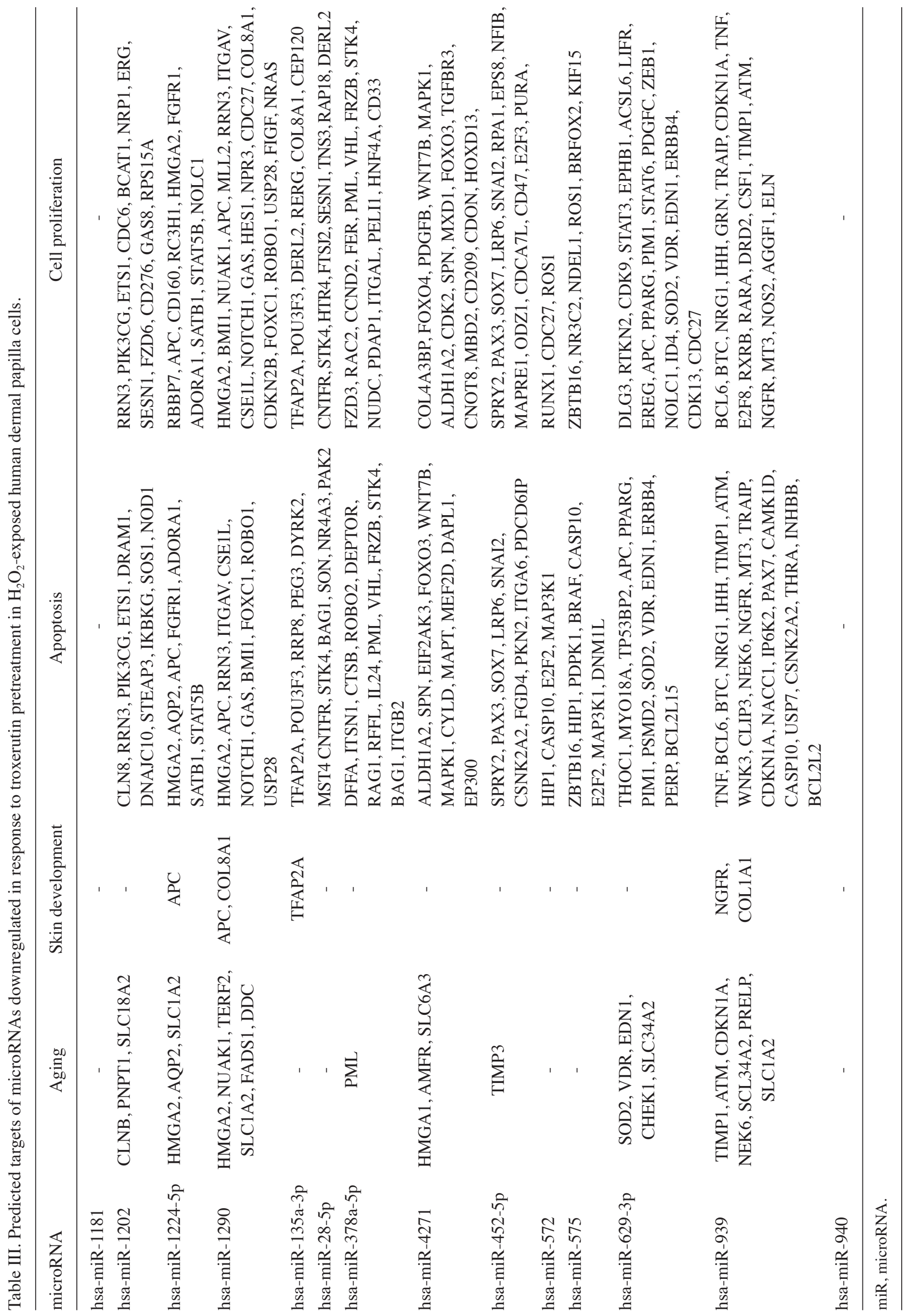


Table IV. Functional annotation chart for miRNAs upregulated in response to troxerutin pretreatment in $\mathrm{H}_{2} \mathrm{O}_{2}$-exposed human dermal papilla cells.

\begin{tabular}{|c|c|c|c|c|c|}
\hline microRNA & $\begin{array}{l}\text { Putative target } \\
\text { genes }(\mathrm{n})\end{array}$ & KEGG pathway & $\begin{array}{l}\text { Genes involved } \\
\text { in the term (n) }\end{array}$ & $\begin{array}{l}\text { Involved genes/ } \\
\text { total genes }(\%)\end{array}$ & P-value \\
\hline \multirow[t]{4}{*}{$\operatorname{miR}-150-3 p$} & \multirow[t]{4}{*}{184} & Wnt signaling pathway & 5 & 2.7 & $6.00 \mathrm{E}-02$ \\
\hline & & Neurotrophin signaling pathway & 4 & 2.2 & $1.20 \mathrm{E}-01$ \\
\hline & & Ubiquitin mediated proteolysis & 4 & 2.2 & $1.50 \mathrm{E}-01$ \\
\hline & & Adherens junction & 3 & 1.6 & $1.70 \mathrm{E}-01$ \\
\hline \multirow[t]{6}{*}{ miR-181a-2-3p } & \multirow[t]{6}{*}{189} & Endocytosis & 6 & 3.2 & 2.90E-02 \\
\hline & & Chemokine signaling pathway & 6 & 3.2 & 3.00E-02 \\
\hline & & Ubiquitin mediated proteolysis & 5 & 2.6 & 3.90E-02 \\
\hline & & Pancreatic cancer & 4 & 2.1 & $3.00 \mathrm{E}-02$ \\
\hline & & Adherens junction & 4 & 2.1 & $3.50 \mathrm{E}-02$ \\
\hline & & Nucleotide excision repair & 3 & 1.6 & $6.40 \mathrm{E}-02$ \\
\hline \multirow[t]{3}{*}{ miR-205-3p } & \multirow[t]{3}{*}{944} & Pathways in cancer & 19 & 2.0 & $2.50 \mathrm{E}-01$ \\
\hline & & MAPK signaling pathway & 17 & 1.8 & $1.70 \mathrm{E}-01$ \\
\hline & & Wnt signaling pathway & 15 & 1.6 & $9.20 \mathrm{E}-03$ \\
\hline \multirow[t]{4}{*}{ miR-21-3p } & \multirow[t]{4}{*}{210} & Cell adhesion molecules & 7 & 3.3 & $4.70 \mathrm{E}-03$ \\
\hline & & Ubiquitin mediated proteolysis & 6 & 2.9 & 2.30E-02 \\
\hline & & Long-term potentiation & 5 & 2.4 & 8.60E-03 \\
\hline & & Oocyte meiosis & 5 & 2.4 & 4.20E-02 \\
\hline \multirow[t]{4}{*}{$\operatorname{miR}-29 b-1-5 p$} & \multirow[t]{4}{*}{265} & Insulin signaling pathway & 5 & 1.9 & 8.50E-02 \\
\hline & & Cell cycle & 4 & 1.5 & 2.00E-01 \\
\hline & & Wnt signaling pathway & 4 & 1.5 & 2.90E-01 \\
\hline & & Jak-STAT signaling pathway & 4 & 1.5 & $3.00 \mathrm{E}-01$ \\
\hline $\operatorname{mir}-3127-5 p$ & 205 & - & - & - & - \\
\hline \multirow[t]{2}{*}{$\operatorname{miR}-371 a-5 p$} & \multirow[t]{2}{*}{351} & Spliceosome & 8 & 2.3 & $4.20 \mathrm{E}-03$ \\
\hline & & Wnt signaling pathway & 7 & 2.0 & $3.60 \mathrm{E}-02$ \\
\hline \multirow[t]{5}{*}{$\operatorname{mir}-3663-3 p$} & \multirow[t]{5}{*}{305} & MAPK signaling pathway & 12 & 3.9 & $5.90 \mathrm{E}-03$ \\
\hline & & Pathways in cancer & 11 & 3.6 & $5.50 \mathrm{E}-02$ \\
\hline & & Neurotrophin signaling pathway & 7 & 2.3 & 2.00E-02 \\
\hline & & Pancreatic cancer & 5 & 1.6 & $3.50 \mathrm{E}-02$ \\
\hline & & Chronic myeloid leukemia & 5 & 1.6 & 4.00E-02 \\
\hline \multirow[t]{4}{*}{$\operatorname{mir}-4298$} & \multirow[t]{4}{*}{185} & Oocyte meiosis & 5 & 2.7 & 8.70E-03 \\
\hline & & Neuroactive ligand-receptor interaction & 5 & 2.7 & $1.20 \mathrm{E}-01$ \\
\hline & & Calcium signaling pathway & 4 & 2.2 & $1.40 \mathrm{E}-01$ \\
\hline & & Phosphatidylinositol signaling system & 3 & 1.6 & $1.10 \mathrm{E}-01$ \\
\hline \multirow[t]{4}{*}{ miR-602 } & \multirow[t]{4}{*}{302} & MAPK signaling pathway & 7 & 2.3 & 2.20E-01 \\
\hline & & Insulin signaling pathway & 6 & 2.0 & 5.30E-02 \\
\hline & & Alzheimer's disease & 6 & 2.0 & $1.00 \mathrm{E}-01$ \\
\hline & & Calcium signaling pathway & 6 & 2.0 & 1.30E-01 \\
\hline
\end{tabular}

miR, microRNA; MAPK, mitogen-activated protein kinase; JAK, Janus kinase; STAT, signal transducers and activators of transcription.

alopecia. A growing body of evidence suggests the role of oxidative stress in alopecia, and that the prevention of oxidative stress may offer novel strategies for the intervention and reversal of alopecia and even graying of hair (17). A previous case study confirmed increased oxidative stress in alopecia areata patients compared with healthy individuals (29). In addition, a study using a mouse model demonstrated that hair dye-induced hair loss is caused predominantly by
$\mathrm{H}_{2} \mathrm{O}_{2}$-induced oxidative stress (30). Oxidative stress stimulates the production of a known inhibitor of hair follicles, tumor growth factor- $\beta$, in DPC cells, which induces the onset of androgenic alopecia (24). Our previous studies demonstrated that troxerutin has a photoprotective effect against UV radiation on dermal fibroblasts and keratinocytes $(6,7)$, and several clinical and theoretical reports have revealed that UV radiation has negative effects on hair growth through the induction 
Table V. Functional annotation chart for miRNAs downregulated in response to troxerutin in $\mathrm{H}_{2} \mathrm{O}_{2}$-exposed $\mathrm{HDP}$ cells.

\begin{tabular}{|c|c|c|c|c|c|}
\hline microRNA & $\begin{array}{l}\text { Putative target } \\
\text { genes (n) }\end{array}$ & KEGG pathway & $\begin{array}{l}\text { Genes } \\
\text { involved in } \\
\text { the term (n) }\end{array}$ & $\begin{array}{c}\text { Involved } \\
\text { genes/total } \\
\text { genes }(\%)\end{array}$ & P-value \\
\hline $\operatorname{miR}-1181$ & 2 & - & - & - & - \\
\hline \multirow[t]{6}{*}{$\operatorname{miR}-1202$} & 241 & Pathways in cancer & 8 & 3.3 & $1.50 \mathrm{E}-01$ \\
\hline & & Insulin signaling pathway & 5 & 2.1 & $1.10 \mathrm{E}-01$ \\
\hline & & Phosphatidylinositol signaling system & 4 & 1.7 & 7.60E-02 \\
\hline & & $\mathrm{ABC}$ transporters & 3 & 1.2 & $1.20 \mathrm{E}-01$ \\
\hline & & mTOR signaling pathway & 3 & 1.2 & $1.50 \mathrm{E}-01$ \\
\hline & & Inositol phosphate metabolism & 3 & 1.2 & $1.60 \mathrm{E}-01$ \\
\hline $\operatorname{miR}-1224-5 p$ & 213 & Axon guidance & 4 & 1.9 & $1.00 \mathrm{E}-01$ \\
\hline \multirow[t]{5}{*}{$\operatorname{miR}-1290$} & 593 & Pathways in cancer & 17 & 2.9 & 4.00E-02 \\
\hline & & Insulin signaling pathway & 13 & 2.2 & 7.60E-04 \\
\hline & & Regulation of actin cytoskeleton & 12 & 2.0 & $6.30 \mathrm{E}-02$ \\
\hline & & MAPK signaling pathway & 12 & 2.0 & $1.90 \mathrm{E}-01$ \\
\hline & & ErbB signaling pathway & 11 & 1.9 & 2.80E-04 \\
\hline miR-135a-3p & 140 & - & - & - & - \\
\hline \multirow[t]{2}{*}{ miR-28-5p } & 157 & MAPK signaling pathway & 7 & 4.5 & $1.20 \mathrm{E}-02$ \\
\hline & & Axon guidance & 4 & 2.5 & $6.60 \mathrm{E}-02$ \\
\hline \multirow[t]{2}{*}{$\operatorname{miR}-378 a-5 p$} & 366 & Wnt signaling pathway & 7 & 1.9 & 3.60E-02 \\
\hline & & TGF- $\beta$ signaling pathway & 4 & 1.1 & $1.70 \mathrm{E}-01$ \\
\hline \multirow[t]{2}{*}{$\operatorname{miR}-4271$} & 361 & Jak-STAT signaling pathway & 7 & 1.9 & 7.80E-02 \\
\hline & & Lysine degradation & 4 & 1.1 & $5.20 \mathrm{E}-02$ \\
\hline \multirow[t]{4}{*}{$\operatorname{miR}-452-5 p$} & 327 & Oocyte meiosis & 8 & 2.3 & 1.30E-03 \\
\hline & & Wnt signaling pathway & 7 & 2.0 & 2.60E-02 \\
\hline & & ECM-receptor interaction & 5 & 1.4 & $3.80 \mathrm{E}-02$ \\
\hline & & Small cell lung cancer & 5 & 1.4 & $3.80 \mathrm{E}-02$ \\
\hline $\operatorname{miR}-572$ & 6 & - & - & - & - \\
\hline \multirow[t]{7}{*}{$\operatorname{miR}-575$} & 241 & MAPK signaling pathway & 8 & 3.3 & 7.70E-02 \\
\hline & & Prostate cancer & 6 & 2.5 & 7.70E-03 \\
\hline & & Melanoma & 5 & 2.1 & 1.70E-02 \\
\hline & & Cell cycle & 5 & 2.1 & $9.60 \mathrm{E}-02$ \\
\hline & & Aldosterone-regulated sodium reabsorption & 4 & 1.7 & $1.90 \mathrm{E}-02$ \\
\hline & & mTOR signaling pathway & 4 & 1.7 & $3.50 \mathrm{E}-02$ \\
\hline & & Androgen and estrogen metabolism & 3 & 1.2 & $9.40 \mathrm{E}-02$ \\
\hline $\operatorname{miR}-629-3 p$ & 441 & PPAR signaling pathway & 6 & 1.4 & $1.20 \mathrm{E}-02$ \\
\hline \multirow[t]{5}{*}{ miR-939 } & 365 & Calcium signaling pathway & 10 & 2.4 & 1.30E-02 \\
\hline & & Regulation of actin cytoskeleton & 9 & 2.1 & $8.90 \mathrm{E}-02$ \\
\hline & & ErbB signaling pathway & 5 & 1.2 & $1.20 \mathrm{E}-01$ \\
\hline & & p53 signaling pathway & 4 & 0.9 & $1.80 \mathrm{E}-01$ \\
\hline & & Wnt signaling pathway & 6 & 1.4 & 2.20E-01 \\
\hline miR-940 & - & - & - & - & - \\
\hline
\end{tabular}

miR, microRNA; mTOR, mammalian targets of rapamycin; MAPK, mitogen-activated protein kinase; ECM, extracellular matrix; Jak, Janus kinase; STAT, signal transducers and activators of transcription; TGF, transforming growth factor; PPAR, peroxisome proliferator-activatedreceptor.

of oxidative stress, acute telogen effluvium and follicular micro-inflammation in follicular stem cells (31-33). Therefore, countering oxidative stress can be considered an important strategy to overcome stress- or androgen-dependent alopecia, and the results of the present study confirmed that troxerutin inhibited oxidative stress-induced cellular damage in the DPC 
A

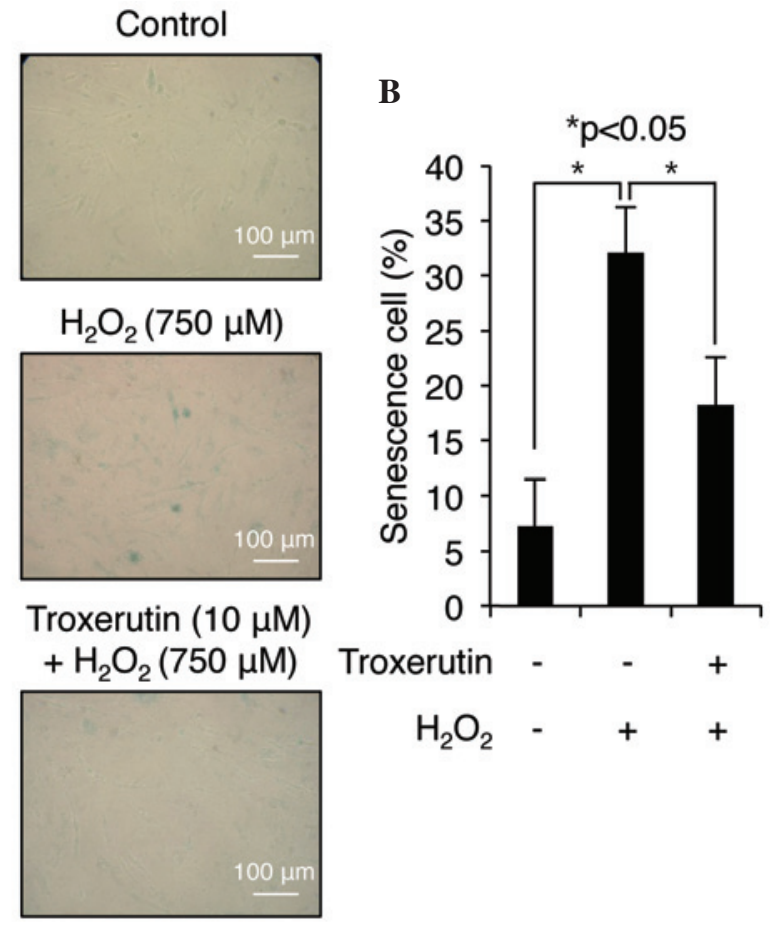

Figure 4. Troxerutin decreases $\mathrm{H}_{2} \mathrm{O}_{2}$-induced senescence in HDP cells. (A) Representative micrographs of control dimethyl sulfoxide-treated HDP cells, HDP cells treated with $\mathrm{H}_{2} \mathrm{O}_{2}$ only and HDP cells pretreated with the indicated dose of troxerutin followed by treatment with $\mathrm{H}_{2} \mathrm{O}_{2}$. The cells were stained for the presence of senescence-associated SA $\beta$-galactosidase activity. (B) Quantification of the percentage of senescent (SA $\beta$-galactosidase-positive) cells. The results are presented as the mean \pm standard deviation of three independent experiments. ${ }^{*} \mathrm{P}<0.05$, compared with the control or $\mathrm{H}_{2} \mathrm{O}_{2}$-treated cells for indicated pairs. HDP, human dermal papilla.

cells. In addition, our previous studies and the present studies demonstrated low levels of cytotoxicity of troxerutin on dermal fibroblasts, keratinocytes and DP cells $(6,7)$. Therefore, further investigation of the clinical effect of topical application of troxerutin to the scalp is required.

Using miRNA microarray analysis, the present study identified 24 miRNAs in the HDP cells treated with troxerutin and $\mathrm{H}_{2} \mathrm{O}_{2}$, which were differentially expressed compared with the cells treated with $\mathrm{H}_{2} \mathrm{O}_{2}$ only. Of these, hsa-miR-602 was the most markedly upregulated by troxerutin in the $\mathrm{H}_{2} \mathrm{O}_{2}$-treated HDP cells (6.91-fold), and has been reported to downregulate the expression of the RASSF1A and TP73 tumor suppressor genes (34). Several reports have revealed that $\mathrm{H}_{2} \mathrm{O}_{2}$ induces the expression of TP73 (35) and that the anticancer drug cisplatin, which has been reported to induce alopecia in patients, stimulates ROS-induced apoptosis and functionally upregulates the expression of p73 (36-38). Although the cellular functions of miR-602, RASSF1A and TP73 have not been investigated in DP cells, the data of the present study suggested that the interaction between miR-602 and the two genes may be functionally involved in ROS-induced cellular stress and even alopecia-associated mechanisms. The biological functions of hsa-miR-575, which was the most downregulated miRNA in the results of the present study, have not been reported previously; however, it may regulate $\mathrm{H}_{2} \mathrm{O}_{2}$-mediated cellular stress. PDPK1, also termed PDK1, is a putative target of miR-575 (Table III) and a well-known kinase, which phosphorylates and activates Akt1 kinase, induces cell proliferation and protects against $\mathrm{H}_{2} \mathrm{O}_{2}$-induced apoptosis $(39,40)$. The present study also classified the biological functions of differentially expressed miRNAs by troxerutin in the $\mathrm{H}_{2} \mathrm{O}_{2}$-treated HDP cells. KEGG pathway analysis of the target genes of the upregulated and downregulated miRNAs revealed 18 and 23 pathways, respectively, were statistically enriched. Among these, the WNT and MAPK signaling pathways, which were the most markedly enriched pathways associated with the target genes of the upregulated and downregulated miRNAs, are involved in the regulation of $\mathrm{H}_{2} \mathrm{O}_{2}$-mediated cellular stress, including apoptosis and antioxidative mechanisms (41-45), suggesting that the miRNAs altered by troxerutin may be involved in protective mechanisms against $\mathrm{H}_{2} \mathrm{O}_{2}$-induced damage through the regulation of these pathways.

In conclusion, the present study revealed a novel role of troxerutin as a putative antioxidant agent in HDP cells. In addition, the results revealed 24 differentially expressed miRNAs and determined the putative involvement of 18 signaling pathways associated with upregulated miRNAs and 23 signaling pathways associated with downregulated miRNAs in the troxerutin-mediated protective effect against $\mathrm{H}_{2} \mathrm{O}_{2}$-induced cell damage. Although further experiments are required to confirm the differentially expressed miRNAs and their target genes, the results of the present study may assist in elucidating the mechanism underlying the troxerutin-mediated protection and miRNA-associated signaling pathways in HDP cells.

\section{Acknowledgements}

This study was supported by a grant from the Korean Health Technology R\&D Project, Ministry of Health and Welfare, Republic of Korea (grant no. HN13C0075). Dr Seunghee Bae was supported by the KU Research Professor Program of Konkuk University.

\section{References}

1. Marzin D, Phi HV, Olivier P and Sauzieres J: Study of mutagenic activity of troxerutin, a flavonoid derivative. Toxicol Lett 35: 297-305, 1987.

2. Boisseau MR, Taccoen A, Garreau C, Vergnes C, Roudaut MF and Garreau-Gomez B: Fibrinolysis and hemorheology in chronic venous insufficiency: a double blind study of troxerutin efficiency. J Cardiovasc Surg (Torino) 36: 369-374, 1995.

3. Lu J, Wu DM, Zheng ZH, Zheng YL, Hu B and Zhang ZF: Troxerutin protects against high cholesterol-induced cognitive deficits in mice. Brain 134: 783-797, 2011.

4. Lu J, Wu DM, Zheng YL, et al: Troxerutin counteracts domoic acid-induced memory deficits in mice by inhibiting CCAAT/enhancer binding protein beta-mediated inflammatory response and oxidative stress. J Immunol 190: 3466-3479, 2013.

5. Babri S, Amani M, Mohaddes G, Alihemmati A and Ebrahimi H: Protective effects of troxerutin on beta-amyloid (1-42)-induced impairments of spatial learning and memory in rats. Neurophysiology 44: pp387-393, 2012.

6. Lee KS, Cha HJ, Lee GT, et al: Troxerutin induces protective effects against ultraviolet $\mathrm{B}$ radiation through the alteration of microRNA expression in human $\mathrm{HaCaT}$ keratinocyte cells. Int J Mol Med 33: 934-942, 2014.

7. Cha HJ, Lee KS, Lee GT, et al: Altered miRNA expression profiles are involved in the protective effects of troxerutin against ultraviolet B radiation in normal human dermal fibroblasts. Int J Mol Med 33: 957-963, 2014.

8. Ping X, Junqing J, Junfeng J and Enjin J: Radioprotective effects of troxerutin against gamma irradiation in V79 cells and mice. Asian Pac J Cancer Prev 12: 2593-2596, 2011. 
9. Maurya DK, Salvi VP and Krishnan Nair CK: Radioprotection of normal tissues in tumor-bearing mice by troxerutin. J Radiat Res 45: 221-228, 2004.

10. Flore R, Gerardino L, Santoliquido A, et al: Enhanced oxidative stress in workers with a standing occupation. Occup Environ Med 61: 548-550, 2004.

11. Hladovec J: Protective effect of oxygen-derived free radical scavengers on the endothelium in vivo. Physiol Bohemoslov 35 97-103, 1986

12. Lu J, Wu DM, Hu B, Zheng YL, Zhang ZF and Wang YJ: NGF-Dependent activation of TrkA pathway: A mechanism for the neuroprotective effect of troxerutin in D-galactose-treated mice. Brain Pathol 20: 952-965, 2010

13. Heck DE, Vetrano AM, Mariano TM and Laskin JD: UVB light stimulates production of reactive oxygen species: unexpected role for catalase. J Biol Chem 278: 22432-22436, 2003.

14. Leach JK, Van Tuyle G, Lin PS, Schmidt-Ullrich R and Mikkelsen RB: Ionizing radiation-induced, mitochondria-dependent generation of reactive oxygen/nitrogen Cancer Res 61: 3894-3901, 2001

15. Driskell RR, Clavel C, Rendl M and Watt FM: Hair follicle dermal papilla cells at a glance. J Cell Sci 124: 1179-1182, 2011.

16. Hibberts NA. Howell AE and Randall VA: Balding hair follicle dermal papilla cells contain higher levels of androgen receptors than those from non-balding scalp. J Endocrinol 156: 59-65, 1998.

17. Trüeb RM: Oxidative stress in ageing of hair. Int J Trichology 1: 6-14, 2009

18. Ripple MO, Henry WF, Rago RP and Wilding G: Prooxidant-antioxidant shift induced by androgen treatment of human prostate carcinoma cells. J Natl Cancer Inst 89: 40-48, 1997.

19. Naito A, Midorikawa T, Yoshino T and Ohdera M: Lipid peroxides induce early onset of catagen phase in murine hair cycles. Int J Mol Med 22: 725-729, 2008.

20. Bahta AW, Farjo N, Farjo B and Philpott MP: Premature senescence of balding dermal papilla cells in vitro is associated with p16 (INK4a) expression. J Invest Dermatol 128: 1088-1094, 2008

21. Lee EJ, Cha HJ, Ahn KJ, An IS, An S and Bae S: Oridonin exerts protective effects against hydrogen peroxideinduced damage by altering microRNA expression profiles in human dermal fibroblasts. Int J Mol Med 32: 1345-1354, 2013.

22. Huang DW, Sherman BT, Tan Q, et al: The DAVID Gene Functional Classification Tool: a novel biological module-centric algorithm to functionally analyze large gene lists. Genome Biol 8: R183, 2007.

23. Luanpitpong S, Nimmannit U, Chanvorachote P, et al: Hydroxyl radical mediates cisplatin-induced apoptosis in human hair follicle dermal papilla cells and keratinocytes through Bcl-2-dependent mechanism. Apoptosis 16: 769-782, 2011.

24. Shin H, Yoo HG, Inui S, et al: Induction of transforming growth factor-beta 1 by androgen is mediated by reactive oxygen species in hair follicle dermal papilla cells. BMB Rep 46: 460-464, 2013.

25. Colavitti R and Finkel T: Reactive oxygen species as mediators of cellular senescence. IUBMB Life 57: 277-281, 2005.

26. Baehrecke EH: miRNAs: micro managers of programmed cell death. Curr Biol 13: R473-R475, 2003.
27. Wang Z, Liu Y, Han N, et al: Profiles of oxidative stress-related microRNA and mRNA expression in auditory cells. Brain Res 1346: 14-25, 2010.

28. Faraonio R, Salerno P, Passaro F, et al: A set of miRNAs participates in the cellular senescence program in human diploid fibroblasts. Cell Death Differ 19: 713-721, 2012.

29. Bakry OA, Elshazly RM, Shoeib MA and Gooda A: Oxidative stress in alopecia areata: a case-control study. Am J Clin Dermatol 15: 57-64, 2014

30. Seo JA, Bae IH, Jang WH, et al: Hydrogen peroxide and monoethanolamine are the key causative ingredients for hair dye-induced dermatitis and hair loss. J Dermatol Sci 66: 12-19, 2012.

31. Trüeb RM: Is androgenetic alopecia a photoaggravated dermatosis? Dermatology 207: 343-348, 2003.

32. Camacho F, Moreno JC and García-Hernández MJ: Telogen alopecia from UV rays. Arch Dermatol 132: 1398-1399, 1996

33. Johnsson A, Kjeldstad B and Melø TB: Fluorescence from pilosebaceous follicles. Arch Dermatol Res 279: 190-193, 1987.

34. Yang L, Ma Z, Wang D, Zhao W, Chen L and Wang G: MicroRNA-602 regulating tumor suppressive gene RASSF1A is overexpressed in hepatitis B virus-infected liver and hepatocellular carcinoma. Cancer Biol Ther 9: 803-808, 2010.

35. Singh M, Sharma H and Singh N: Hydrogen peroxide induces. apoptosis in HeLa cells through mitochondrial pathway. Mitochondrion 7: 367-373, 2007.

36. Surendiran A, Balamurugan N, Gunaseelan K, Akhtar S, Reddy KS and Adithan C: Adverse drug reaction profile of cisplatin-based chemotherapy regimen in a tertiary care hospital in India: An evaluative study. Indian J Pharmacol 42: 40-43, 2010.

37. Casares C, Ramírez-Camacho R, Trinidad A, Roldán A, Jorge E, and García-Berrocal JR: Reactive oxygen species in apoptosis induced by cisplatin: review of physiopathological mechanisms in animal models. Eur Arch Otorhinolaryngol 269: 2455-2459, 2012.

38. Gong JG, Costanzo A, Yang HQ, et al: The tyrosine kinase c-Abl regulates $\mathrm{p} 73$ in apoptotic response to cisplatin-induced DNA damage. Nature 399: 806-809, 1999.

39. Wang Z, Cui M, Sun L, et al: Angiopoietin-1 protects $\mathrm{H} 9 \mathrm{c} 2$ cells from $\mathrm{H}_{2} \mathrm{O}_{2}$-induced apoptosis through AKT signaling. Biochem Biophys Res Commun 359: 685-690, 2007.

40. Mora A, Komander D, van Aalten DM and Alessi DR: PDK1, the master regulator of AGC kinase signal transduction. Semin Cell Dev Biol 15: 161-170, 2004.

41. Finkel T: Signal transduction by reactive oxygen species. J Cell Biol 194: 7-15, 2011.

42. Shin SY, Kim CG, Jho EH, et al: Hydrogen peroxide negatively modulates Wnt signaling through downregulation of beta-catenin. Cancer Lett 212: 225-231, 2004.

43. Korswagen HC: Regulation of the Wnt/beta-catenin pathway by redox signaling. Dev Cell 10: 687-688, 2006.

44. Song X, Xu A, Pan W, et al: Minocycline protects melanocytes against $\mathrm{H}_{2} \mathrm{O}_{2}$-induced cell death via JNK and p38 MAPK pathways. Int J Mol Med 22: 9-16, 2008

45. Ismail NS, Pravda EA, Li D, Shih SC and Dallabrida SM Angiopoietin-1 reduces $\mathrm{H}_{2} \mathrm{O}_{2}$-induced increases in reactive oxygen species and oxidative damage to skin cells. J Invest Dermatol 130: 1307-1317, 2010. 